\title{
No Way Out or No Way In? The Effect of Standardization, Licensing, and Skills Specificity of the Initial and Target Occupations on Status Mobility
}

\author{
Basha Vicari · Stefanie Unger
}

Published online: 25 June 2020

(C) The Author(s) 2020

\begin{abstract}
Occupational mobility is becoming increasingly important today owing to technological change and changing requirements in the employment system. This article examines the extent to which institutional characteristics of occupations hamper intragenerational occupational mobility on the labor market. By combining data from the Adult Cohort of the German National Educational Panel Study (NEPS) with occupational information from the German Federal Employment Agency, we test the power of the characteristics of the initial and target occupations to explain horizontal and vertical status mobility. The occupational characteristics that we focus on are the standardization of certificates, occupational licensing, and the specificity of skills. Using multinomial logistic regression, we find that both initial and target occupations with such characteristics might generate mobility constraints and impede the correction of a disadvantageous starting position. Status increases are mainly possible from standardized to nonstandardized, from specific to nonspecific and, in some instances, from nonlicensed to licensed occupations.
\end{abstract}

Keywords Occupational mobility $\cdot$ Occupational characteristics $\cdot$ Status increase Target job · NEPS

B. Vicari $(\bowtie) \cdot$ S. Unger

Institute for Employment Research (IAB)

Regensburger Str. 104, 90478 Nuremberg, Germany

E-Mail: Basha.Vicari@iab.de

S. Unger

E-Mail: Stefanie.Unger@iab.de 


\section{Kein Weg raus oder kein Weg rein? Die Wirkung von Standardisierung, Lizensierung und Spezifität des Ausgangs- und Zielberufs auf Statusmobilität}

Zusammenfassung Vor dem Hintergrund des technologischen Wandels und sich verändernder Anforderungen im Beschäftigungssystem wird berufliche Mobilität heute immer bedeutsamer. Dieser Beitrag untersucht, inwiefern institutionelle Eigenschaften von Berufen intragenerationaler Statusmobilität am Arbeitsmarkt entgegenstehen. Durch die Kombination von Daten der Erwachsenenkohorte des Nationalen Bildungspanels (NEPS) mit Berufsinformationen der Bundesagentur für Arbeit testen wir die Erklärungskraft von Merkmalen der Ausgangs- und Zielberufe auf horizontale und vertikale Statusmobilität. Die Berufsmerkmale in unserem Fokus sind Standardisierung von Zertifikaten, Berufslizenzen und Spezifität von Fachkenntnissen. Mit multinomialen logistischen Regressionen finden wir, dass sowohl Ausgangs- als auch Zielberufe mit solchen Eigenschaften Mobilitätsbarrieren hervorrufen und den Aufstieg aus benachteiligten Positionen behindern können. Aufstiege sind vor allem aus standardisierten in nichtstandardisierte, von spezifischen in unspezifische und in bestimmten Fällen von nichtlizenzierten in lizenzierte Berufe möglich.

Schlüsselwörter Berufsmobilität · Berufsmerkmale · Sozialer Aufstieg · Zielberuf · NEPS

\section{Introduction}

Owing to technological progress, the rapidly changing requirements of occupations are making occupational mobility increasingly important for successful integration into the labor market. Although available positions in some occupations are decreasing, there are other occupations with an ever-growing demand for new employees (Dengler and Matthes 2018). To successfully keep pace with these structural changes, individuals must constantly be gaining further qualifications and be prepared to change occupations. Occupational mobility is the vehicle for intragenerational status mobility and development (Hillmert 2011; Sørensen 1975). Individual career development, however, is subject to the constraints of the labor market and its institutional regulations. Such institutional regulations determine, for example, the level of mobility rates in a society (Rhein et al. 2013). They promote or impede assignments to social positions and thus significantly affect social inequality (Reichelt and Abraham 2017).

The way in which qualifications are assigned to labor market positions is one such institutional regulation. There are qualification-based and organizational labor markets resulting in completely different implications for status mobility (Maurice et al. 1979). In highly stratified qualification-based labor markets, the link between qualifications and allocation to positions is strong (Allmendinger 1989; Müller and Shavit 1998; Solga and Konietzka 1999). Consequently, these labor markets are fragmented into closed occupational segments, where access is conditional on holding 
a certain certificate (Bol and Weeden 2015; Haupt 2012, 2016; Kleiner 2000). Such conditions complicate the correction of disadvantageous starting positions by occupational mobility. Organizational labor markets, in contrast, are less stratified, and the link between qualifications and positions is weaker. There, economic success depends on individual signals of trainability rather than on particular credentials (Bills 2003; Hillmert 2011; König and Müller 1986). These markets allow for changing occupations even later in the career to improve one's status (Hanushek et al. 2011).

The mechanisms that cause mobility constraints through the institutional regulation of labor markets have not yet been exhaustively empirically researched. Although most studies on occupational mobility describe the assignment of qualifications to positions as an institutional function of occupations, they exploit only individual-, job-, or firm-level characteristics to explain mobility rates (e.g., Becker and Blossfeld 2017; Dütsch et al. 2013; Gangl 2003; Hall 2010; Hillmert 2011; Mayer et al. 2010; Schmelzer 2012). Only a few recent studies have attempted to empirically measure the regulatory effect of occupations. They have succeeded in demonstrating the power of the occupational characteristics themselves to explain matching efficiencies and mobility patterns (Damelang et al. 2015, 2018; Dengler et al. 2016; Reichelt and Abraham 2017; Vicari 2018).

In this article, we analyze how the characteristics of occupations representative of a qualification-based labor market, such as the German labor market, affect individual horizontal and vertical status mobility. Therefore, we build on previous studies addressing the institutional regulation of occupations and extend them in two respects. First, we embed our analyses in a more general concept of status development instead of focusing on the isolated event of matching, duration of the first occupation, or income development, which have been the focus of most previous studies. Status development means that individuals have improved their social position through occupational mobility (Hillmert 2011). For this reason, as early as 1975, Sørensen called for empirical research on occupational and status mobility to be combined. We do so by examining how occupations affect individual upward or downward developments across status positions-and not only across skills or requirement levels - to obtain a deeper understanding of how occupations and social inequality are related.

Second, we explicitly model the effects of the characteristics of the initial and target occupations, whereas earlier studies focused only on the characteristics of the initial occupations. The institutional regulation of occupations affects occupational mobility in two ways-it determines the likelihood of quitting and entering an occupation. In the case of qualification-based labor markets, occupation-specific skills can best be used and remunerated in a corresponding position (Damelang et al. 2015), which decreases the incentives for quitting an occupation. On the other hand, occupation-specific skills can be used as a prerequisite for entering an occupation. Theories that have usually described the assignment of qualifications to positions, namely, the theories of human capital, sorting, and closure, are all oriented toward access to an occupational segment. By turning our attention to the characteristics of the target occupation, we aim to follow these theories more closely. Therefore, in our hypotheses, we distinguish between the effect of occupational characteristics on quitting an initial occupation and entering a target occupation. The first type of 
hypothesis allows us to compare our results derived from the broader status concept with those of earlier studies derived from a narrower mobility rate concept; the second type contributes to new insights into mobility barriers between occupational segments.

The occupational characteristics that we use to measure institutional regulations are-in line with some earlier studies - the standardization of certificates, occupational licensing, and the specificity of skills. If, for example, an occupation is only accessible with a standardized certificate, an occupational license, or a highly specific set of skills, it may be rather difficult to enter it by switching occupation. We consider all these aspects when answering our research question: how do the characteristics of the initial and target occupations affect mobility across status positions?

For our analyses, we use data from the Adult Cohort of the National Educational Panel Study (NEPS), which we combine with occupational information from various statistics of the German Federal Employment Agency. We start with an overview of the research on status and occupational mobility (Sect. 2). After a brief description of the theoretical background of occupational regulation, we derive hypotheses about the effect of the characteristics of the initial and target occupation on different directions of status mobility (Sect. 3). In Sect. 4, we describe the data, the central variables, and the statistical methods used. Our results (Sect. 5) include descriptive and multivariate findings, which we summarize and discuss in Sect. 6.

\section{Previous Research}

\subsection{Intragenerational Status Mobility and Occupations}

Sorokin (1927, p. 133) defined social mobility as "any transition of an individual [...] from one social position to another". ${ }^{1}$ Models of social stratification assume that individuals sharing similar social positions (educational attainment, income, occupational prestige) also share similar experiences in life and thus have similar opportunities to realize their socioeconomic success (Ditton and Maaz 2011). As the individually acquired social position or status is mainly based on occupational positions, the most prominent status measures such as SIOPS, ISEI, MPS, and EGP 2 are oriented toward occupations. To quote Kleining and Moore (1960, p. 88), the "job title itself seems to be the best symbol to be used for a social classification." It is still true, especially for intragenerational mobility, that status mobility is closely connected with occupational mobility (Jarvis and Song 2017).

Research on status mobility, however, has treated occupations merely as carriers of class attributes (Mayer and Carroll 1987; Solga and Konietzka 1999, p. 25) without recognizing their function of regulating matching and creating constraints. Instead,

\footnotetext{
1 As we follow this definition, we use the terms social and status mobility synonymously throughout the article.

2 These refer to the Standard Index of Occupational Prestige Scale (SIOPS), the International SocioEconomic Index of Occupational Status (ISEI), the Magnitude Prestige Scale (MPS), and the EriksonGoldthorpe-Portocarero Classes (EGP).
} 
this research has focused on individual and structural inequality determinants. From the individual perspective, economic, social, and cultural capital improve information and networks for climbing the social ladder. The structural perspective, on the other hand, considers institutional differences and economic conditions that lead to individual unequally distributed opportunities for career development. These are, for example, the types of labor markets, educational systems, and welfare regimes, as well as gender segregation, technological progress, or demographic conditions (e.g., Becker and Blossfeld 2017; Hillmert 2011; Jarvis and Song 2017; König and Müller 1986; Leuze 2007; Solga and Konietzka 1999).

\subsection{Research on Occupational Mobility}

Although research on status mobility is primarily concerned with inequality in opportunities, research on occupational mobility mainly looks at causes and consequences of switching occupations. There are different reasons why individuals quit their (trained) occupation. They do it voluntarily if they can reach a higher position, earn more money, increase their satisfaction, or better balance their work with family duties or health issues (e.g., Fitzenberger and Spitz-Oener 2004; Fletcher 2012; Fuller 2008; Hall 2010; Kambourov and Manovskii 2009; Longhi and Brynin 2010; Topel and Ward 1992). However, occupational mobility may also be forced if, for example, it serves to avoid unemployment or regional relocation. Often, such involuntary moves are accompanied by a loss of income or status (e.g., Hall 2010; Kracke et al. 2018; Reichelt and Abraham 2017).

Individual reasons determine not only occupational mobility rates but also their timing. Over the working life, occupational mobility decreases with the accumulation of occupation-specific skills. Career starters are particularly mobile because they first have to collect information on potential careers and earning developments and then have to adjust their job expectations accordingly (Johnson 1978; Miller 1984). If the possibility of readjustment is hampered by mobility constraints of closed occupational segments, a disadvantageous first position can negatively affect the entire later career path (Blossfeld 1985; Wolbers 2008). This gains in relevance in times when technological progress alters occupational requirements and leads to a structural change in the occupational landscape. Over the last decades, we have indeed observed an expansion of occupational mobility, even in qualification-based labor markets with traditionally low rates (Dütsch et al. 2013; Giesecke and Heisig 2010; Mayer et al. 2010).

The expansion of occupational mobility has generated an upswing in occupational mobility research, as the mechanisms behind the position assignments have come to the fore. From this new perspective, occupations themselves are seen as institutions defining the scope of action between employers and potential employees within the matching process. Moreover, these recent studies have empirically tested the regulatory effect of occupations by including certain occupational characteristics in their analyses. For example, Damelang et al. (2015) show that occupations with standardized certificates and closed occupations with a low wage dispersion reduce the probability of quitting the first occupation. Reichelt and Abraham (2017) find that licensed occupations and occupations with specific skills also lower the proba- 
bility of quitting an occupation. For occupational licensing, Vicari (2018) confirms a negative effect on horizontal and vertical occupational mobility. For occupations with standardized certificates and specific skills, however, the effects differ from those of the other two studies. Looking at the occupations' effect on matching, Dengler et al. (2016) show that occupations with standardized certificates and licensed occupations improve the matching efficiency, whereas task diversity diminishes it. Additionally, Damelang et al. (2018) reveal that licensed occupations have a negative effect on both vacancy duration and occupational mobility. Moreover, there are many studies dealing with the effect of licensed occupations on wage distributions and inequalities (e.g., Bol and Weeden 2015; Gittleman et al. 2018; Haupt 2012, 2016; Haupt and Witte 2016; Weeden 2002).

\section{Theoretical Considerations on Occupations and Status Mobility}

Sørenson and Kalleberg (1981, p. 52) consider the labor market "arenas for the matching of persons to jobs," in which candidates with certain skills compete for vacant positions (Abraham et al. 2018). Employers try to fill these positions with the most productive candidates at the lowest possible training costs. However, filling a position is a situation of uncertainty, as employers cannot assess the productivity of candidates ex ante. Exchanges under uncertainty can generally be solved by institutions, as these regulate the scope of action between negotiators (Esser 2006) and thus reduce the transaction costs of matching for both sides (Williamson 1981). This situation also applies to labor markets. Occupations as institutions link the qualifications of employees acquired in the education system to the ideal-typical requirement profiles of positions (Abraham et al. 2018). In the matching situation, occupations help employers to assess the productivity of candidates and help candidates to assess the conditions of the job (Georg and Sattel 2006). However, the strength of the link between qualifications and positions varies considerably across labor market types.

In the following, we discuss how the occupational characteristics that we focus on, that is standardized certificates, occupational licensing, and skills specificity, which all determine the job assignment, may affect occupational and status mobility. To disentangle the effect of these characteristics on the likelihood of quitting or entering an occupation, we draw separate hypotheses for the initial and target occupations.

\subsection{Occupations with Standardized Certificates and Status Mobility}

The productivity signals of candidates are most reliable for employers if standardized certificates based on standardized qualifications confirm the candidates' skills sets. In Germany, mainly apprenticeship occupations are regarded as standardized, as they are uniformly organized in accordance with the German Vocational Training Act (Konietzka 2008). Recognized vocational school training programs (e.g., nurse) and formal further education (e.g., master craftsman or technician) are also considered standardized because they are at least uniformly organized at the state level (Allmendinger 1989; Solga and Konietzka 1999). According to the human capital theory of Becker (1962), educational certificates directly verify that a candidate has 
acquired valuable skills for a position. In contrast, the queueing theory by Thurow (1975) assumes that education can be used to screen job seekers regarding trainability. In this concept, educational certificates do not signal actual skills but an abstract kind of productivity (Bills 2003). However, in both cases, the information asymmetry is lower in occupations with standardized certificates than in occupations without such certificates.

Since the labor market for standardized occupations is strongly qualificationbased and marked by the risk for the devaluation of occupation-specific skills if occupations are switched (Blossfeld and Mayer 1988; Kambourov and Manovskii 2009; Sengenberger 1987), we generally expect a high rate of firm switches but a low rate of occupation switches. For example, a baker could easily switch across different bakeries, but would devaluate his/her skills when becoming a painter. On the other hand, there are established career paths in qualification-based labor markets, making status improvements more likely (Vicari 2018). In this example, the baker could become a master baker by further qualification. Thus, we assume that workers in initial occupations that usually require standardized certificates are less likely to quit through horizontal and downward mobility and are more likely to quit through status increases (hypothesis 1a).

As employers can rely on standardized certificates to signal general productivity or even ready-to-use skills, they prefer candidates holding such certificates to minimize training costs. This makes standardized certificates a type of informal access restriction that hampers occupational mobility. Therefore, we assume that target occupations that usually require standardized certificates are less likely to be entered through any kind of horizontal or status mobility (hypothesis $1 b$ ).

\subsection{Occupational Licensing and Status Mobility}

In addition to the informal access restrictions by standardized certificates, occupational licensing represents much stronger formal access restrictions that close respective labor market segments (Abraham et al. 2018). In Germany, licensing laws are legitimized by the protection of basic commodities of outstanding importance, such as public safety, public health, education, and the rule of law, which must all be provided in perfect quality (Bryson and Kleiner 2010; Haupt 2016). In licensed occupations, access and practice or even just the use of an occupational title is subject to the formal prerequisite of a qualification through legal or administrative authorities (Vicari 2014). Licensed occupations are, for example, physicians, lawyers, or teachers. Accordingly, occupational licensing excludes potential competitors that do not hold a license, especially if the occupational groups manage to collectively organize themselves and establish legal boundaries around the access to an occupation (Haupt 2012; Kleiner 2000). The reduction of competition may generate advantages such as higher wages for insiders (Bol and Weeden 2015; Haupt 2016; Haupt and Witte 2016; Kleiner 2000; Weeden 2002). The advantageous conditions in licensed occupations and the high devaluation costs upon quitting should in turn reduce mobility incentives. Moreover, the reduced competition in licensed occupations should at least make an involuntary social decline less likely (Vicari 2018). For that reason, 
we expect that workers in licensed initial occupations are less likely to quit through any kind of horizontal or status mobility (hypothesis $2 a$ ).

Because occupational licensing restricts access to respective labor markets, we would generally assume that access to a licensed occupation by an occupational switch is rather unlikely. However, there are some occupations representing a "prestage" of a licensed occupation, requiring a special degree but not the license. For example, a pharmacist has to study pharmacy, take a state examination, and obtain a license. However, with just a pharmacy degree without the license, one could work as a pharmaceutical specialist in the pharma industry. Another example would be the preschool teacher, which is a licensed occupation in Germany, and a childcare worker who has similar training without obtaining the license. Both work in a kindergarten but have different duties. Again, another example would be a nonlicensed legal expert and a licensed lawyer. By investing in further qualification and obtaining a license, the status from the "pre-stage" occupation could increase to the licensed occupation. Thus, we assume that licensed target occupations are less likely to be entered through horizontal or downward mobility and are more likely to be entered through status increases (hypothesis $2 b$ ).

\subsection{Specificity of Skills and Status Mobility}

Occupational certificates and licenses signal not only whether the skills of candidates are ready-for-use but also how high the share of specific skills is. In vocational training, up to two-thirds of the provided skills are occupation-specific, whereas in academic training, skills are considered to be mainly general (Hall 2010). Skills specificity affects the utilization opportunities of the acquired skills (Becker 1962; Kambourov and Manovskii 2009). Although general skills are universally applicable, the transferability of occupation-specific skills is only easy across firms, but not across occupations (Müller and Shavit 1998). The more specific the skills are, the fewer opportunities for utilization exist in other occupations, and the less incentives there are to quit an occupation in which these skills are fully remunerated (Damelang et al. 2015; Vicari 2018). However, there are-similar to the mechanism of standardized certificates - established career paths from highly specific occupations to less specific occupations that are concurrently associated with status increases. A widespread example is the rise of the specialized skilled worker who becomes the less specialized manager. Hence, we assume that workers in highly specific initial occupations are less likely to quit through horizontal or downward mobility and more likely to quit through status increases (hypothesis $3 a$ ).

Although skills specificity does not create formal or informal restrictions, access to an occupation requiring a very specific skill set may prove difficult if not exactly these skills are provided because then the training costs would increase. Thus, we assume that entry into a very specific target occupation is less likely to take place through any kind of horizontal or status mobility (hypothesis $3 b$ ). 


\section{Data, Variables, and Empirical Strategy}

\subsection{Data and Sample Restrictions}

We use multiple data sources to investigate the effect of occupational characteristics on the direction of status mobility. We obtain information on job episodes, job and firm characteristics, and individual characteristics from the Adult Cohort of the National Educational Panel Study (NEPS; https://doi.org/10.5157/NEPS:SC6:9.0.1) It contains representative longitudinal survey data, for example, on the development of competencies, on educational processes and decisions, on employment trajectories, and on returns to education over the life course (Blossfeld et al. 2011). The Adult Cohort of NEPS comprises more than 17,000 individuals born between 1944 and 1986 living in Germany. Detailed education and employment histories were collected retrospectively for the time before the first interview, and since then as an annual panel conducted by a telephone or computer-assisted face-to-face interview. The outstanding reliability of the retrospectively collected information in the NEPS data is achieved by applying "dependent interviewing" and by the live edition in a validation module during the interview (for details see Allmendinger et al. 2019).

For occupational characteristics, we employ several indicators from different databases. The indicators for standardized certificates and for occupational licensing (developed by Vicari 2014) are based on BERUFENET, the online career information portal provided by the German Federal Employment Agency (https://berufenet. arbeitsagentur.de) - a rich job title database similar to the US O*NET. The indicator for skills specificity is based on the requirements matrix in BERUFENET, providing core competencies for each occupation (for details see Matthes and Vicari, forthcoming). We also use information on occupational size, unemployment rate, and occupational median wage to control for labor market tightness. This information comes from the official employment statistics of the German Federal Employment Agency.

Our sample is restricted to individuals with at least one employment episode in the data. We further restrict our sample to employment episodes that have a coded job title, thus excluding unspecified helper jobs from the analyses. This restriction slightly diminishes the informative value of our findings. However, without a job title, we cannot assign any occupational information, which is the core element of our analysis. Moreover, this restriction only affects a marginal number of episodes, as most helper jobs do have a job title. We also remove all first employment episodes that last less than 3 months to avoid biases caused by holiday jobs. As the indicators for occupational characteristics are currently available only for the year 2012, and as the further control variables (for example, the occupational medium wage) are only available from 1999 onward, we further restrict our sample to employment episodes starting in the year 1999. In this way, we try to reduce noise in the occupational information. Hence, our analysis sample is reduced to 10,821 individuals, including a total of 25,964 employment episodes occurring between 1999 and 2017. 


\subsection{Measuring Status Mobility}

Our dependent variable is the discrete choice outcome of status mobility. We measure it in two steps. First, we identify an event of mobility when there is a switch of the occupational main-group ${ }^{3}$ (two-digit code of the German classification of occupations KldB2010). Occupational changes in the two-digit code may appear to be a rough measure. However, this way we ensure a clear distinction between the actual bundles of activities of occupations. As we control for the requirement level $^{4}$ of occupations in our analyses, we regard this conservative measure of real changes in working content and qualification prerequisites as sufficiently detailed to test our hypotheses. In a second step, we measure status increases and decreases by employing the "International Socio-Economic Index of Occupational Status" (ISEI) established by Ganzeboom et al. (1992) and updated in 2008. In our sample, ISEI scores range from 11.6 for skilled occupations in horticulture and floristry to 88.9 for expert occupations in law and public administration, with an overall average of 46.1. We combine both steps in a variable with four categories. If there is only job mobility without switches of the occupational main group or changes in the ISEI score, we code this as "no mobility." An example is a switch from skilled occupations in printing technology to skilled occupations in technical media design. Both belong to occupations in papermaking, printing, and technical media design and have close ISEI scores of 30.5 and 35.3 respectively. To measure "horizontal mobility" at a constant status level, we create a belt of plus and minus $10 \%$ of the ISEI score. This category applies when the initial and target occupations belong to different occupational main groups, but differ by less than 7.7 ISEI points from each other. An example is the switch from skilled occupations in financial services, accounting and tax consultancy (ISEI score 48.1) to skilled occupations in purchasing, sales, and trading (ISEI score 50.4). When the target occupation's ISEI score is more than 7.7 points higher than the initial occupation's ISEI score, we code it as "upward mobility"; when its score is lower by more than 7.7 points, we code it as "downward mobility." Examples of upward mobility would be the switch from skilled occupations in business management and organization (ISEI score 51.8) to expert occupations in education and social work (ISEI score 70.5) and the switch

Table 1 Frequencies of status mobility

\begin{tabular}{lll}
\hline Status mobility & Frequency & Percentage \\
\hline No mobility & 11,829 & 45.56 \\
Horizontal mobility & 4,143 & 15.96 \\
Upward mobility & 5,533 & 21.31 \\
Downward mobility & 4,459 & 17.17 \\
Total & 25,964 & 100.0 \\
\hline
\end{tabular}

Source: NEPS-SC6 restricted sample; $N$ persons $=10,821$; years 1999-2017, own calculations

\footnotetext{
3 Technically, we should report the change in occupational main-groups in the entire article. In line with the literature, however, we instead speak of occupations to ensure greater comprehensibility.

4 There are four requirement levels: unskilled, skilled, specialist, and expert, corresponding to the usually required qualification for a position (Paulus and Matthes 2013).
} 
within the occupational main group of medical and health care occupations from specialist occupations in nursing and emergency medical services (ISEI score 56.0) to expert occupations in human medicine and dentistry (ISEI score 88.7). Examples of downward mobility would be the reverse of those upward switches or if there were a switch from skilled occupations in law and public administration (ISEI score 54.3) to unskilled occupations in traffic and logistics (ISEI score 17.7). In our sample, most jobs were switched within the same occupational main group and ISEI score, which were coded as not mobile (Table 1). We also see that vertical status movements are more common than horizontal ones.

\subsection{Measuring Occupational Characteristics and Control Variables}

The regulatory characteristics of occupations in our focus are standardized certificates, occupational licensing, and specificity of skills. The indicator for standardization, which is derived from the attribute "career group" from BERUFENET, reflects how many individual occupations within an occupational main group are associated with a standardized certificate. Analog, the indicator for occupational licensing, uses the attribute "legal entry regulation" from BERUFENET and shows how many individual occupations within an occupational main group are licensed (for details see Vicari 2014). The indicator of the specificity of skills is based on the measure of similarity between occupations by Matthes and Vicari (forthcoming). It is developed on the basis of the requirements matrix in BERUFENET that records competencies for each individual occupation. The indicator uses information on the core competencies, "which are indispensable for the exercise of the occupation, i.e., constitute the core of an occupation" (Dengler et al. 2014, p. 15). The indicator calculates the share of overlapping core competencies among all occupations. To obtain a measure of skills specificity, we sum all associated pairwise relationships for each individual occupation with more than 5\% overlap. Their sum, subtracted from 1, is normalized to a value between 0 (= not specific) and 1 (= very specific). Again, analogous to the two previous indicators, this indicator displays how many individual occupations within an occupational main group are skills-specific (for details see Vicari 2018).

In addition to the main regulatory characteristics of occupations, we include further occupational variables in our models to control for labor market tightness. We include information on occupation size, measured as the ratio of individuals employed in a particular occupation, the ratio of unemployed in an occupation, and the occupational median wage from the official employment statistics of the German Federal Employment Agency. The size of an occupation affects individual mobility behavior because shrinking occupations increase the likelihood of losing one's job and subsequently having to switch occupations, whereas large occupations increase the likelihood of finding a new job. Similarly, a high occupational unemployment rate increases the risk of mobility and lowers the chance of entry into this occupation. If the median wage of an occupation is high, workers are less likely to quit and it is an attractive target occupation. Moreover, we include a number of additional individual variables (sex, age at career start, education), job variables (number of employment episodes, type of job change, requirement level, same employer, employment status, civil service, temporary contract, workplace location), and the type of industry into 
Table 2 Descriptive statistics of occupational characteristics

\begin{tabular}{lllll}
\hline $\begin{array}{l}\text { Occupational } \\
\text { characteristics }\end{array}$ & Mean & $\begin{array}{l}\text { Standard } \\
\text { deviation }\end{array}$ & Minimum & Maximum \\
\hline $\begin{array}{l}\text { Standardized } \\
\text { certificates }\end{array}$ & 0.655 & 0.201 & 0.024 & 0.921 \\
Licensing & 0.145 & 0.182 & 0 & 0.652 \\
Specificity & 0.716 & 0.166 & 0.210 & 1 \\
\hline
\end{tabular}

Source: NEPS-SC6 restricted sample; $N$ persons $=10,821 ; N$ observations $=25,964$; years 1999-2017, own calculations

our models, as these factors are known to affect career movements (Jarvis and Song 2017). Controlling for all these relevant variables enables us to single out the effect of occupational characteristics. ${ }^{5}$

In Table 2, we find that two-thirds of the employment episodes in our sample are standardized, $15 \%$ are licensed, and $72 \%$ are highly skills-specific. Remarkably, the maximum of licensed occupations is $65 \%$ and the minimum skills specificity is $21 \%$. This means that no occupational main group is fully licensed or completely nonspecific. For all occupational variables and most of the job and industry variables, we distinguish between the attributes of the initial and target jobs. Therefore, an initial job corresponds to the target job in the previous employment episode.

\subsection{Research Design and Methodology}

When individuals switch jobs, they can do so within one occupation, across occupations, and with or without status changes. However, they cannot do everything at once. The outcome states compete with each other; thus, we use the so-called competing risk models. Assuming that the respective outcome states are independent and that their probabilities of occurrence are not mutually dependent (assumption of independence of irrelevant alternatives [IIA]), we can simultaneously estimate the likelihood of all types of mobility by using multinomial logistic regression (m-logit) (Windzio 2013, p. 225). Similar to the odds ratios of the binary logistic regression, we can describe the effects of the covariates on the probability of the dependent variables as relative risk ratios $\Omega_{m \mid n}\left(x_{i}\right)$. However, these should always be interpreted in relation to the basic category (b). We coded the nonmobile cases into the basic category:

$$
\Omega_{m \mid n}\left(x_{i}\right)=\frac{P\left(y=m \mid x_{i}\right)}{P\left(y=b \mid x_{i}\right)}=\frac{\frac{\exp \left(x_{i} \beta_{m}\right)}{\sum_{i=1}^{I} \exp \left(x_{i} \beta_{i}\right)}}{\frac{\exp \left(x_{i} \beta_{b}\right)}{\sum_{i=1}^{I} \exp \left(x_{i} \beta_{i}\right)}}=\frac{\exp \left(x_{i} \beta_{m}\right)}{\exp \left(x_{i} \beta_{b}\right)}
$$

To make the effect strength between coefficients of the distinct outcome states comparable and to simplify interpretations, we convert the relative risk ratios into

\footnotetext{
5 Testing the whole range of variables for multicollinearity reveals that there is no such problem between the occupational characteristics. Only the variable firm size displays a high value for the "variable influence factor." As it has no explanatory power throughout all the models, we exclude it from our analyses.
} 
average marginal effects (AMEs) (Best and Wolf 2012) and present them in the results tables and plots accordingly.

Recently, there have been strong criticisms of nonlinear probability models, which include the m-logit model (Breen et al. 2018). Therefore, we also model independent linear regressions for our four outcome states to check the robustness of our estimations. These independent linear regressions produce very similar, sometimes stronger or more significant coefficients. From our point of view, however, these can be interpreted less accurately in terms of competing risks. Therefore, we keep the $\mathrm{m}$-logit as a better fitting and conservative model.

\section{Empirical Results}

\subsection{Correlation of Status and Occupational Characteristics}

To obtain a first impression of the relationship between status positions and our three occupational characteristics, we run simple partial regressions and use added variable plots to visualize these correlations (Fig. 1). The plots reveal that there is a negative correlation between standardized certificates and the ISEI scores, a positive correlation between occupational licensing and the ISEI scores, and a slightly negative correlation between skills specificity and the ISEI scores. This implies that mostly the occupations with a lower status are highly standardized. This is plausible because academic positions, which often have a high ISEI score, are not associ-
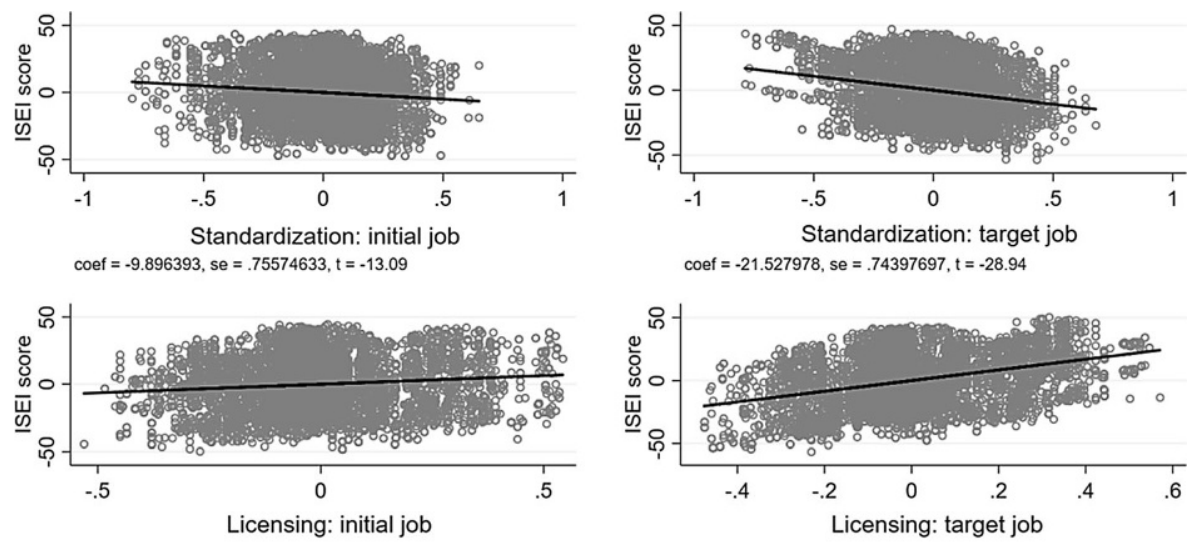

coef $=42.411159$, se $=.92085397, \mathrm{t}=46.06$
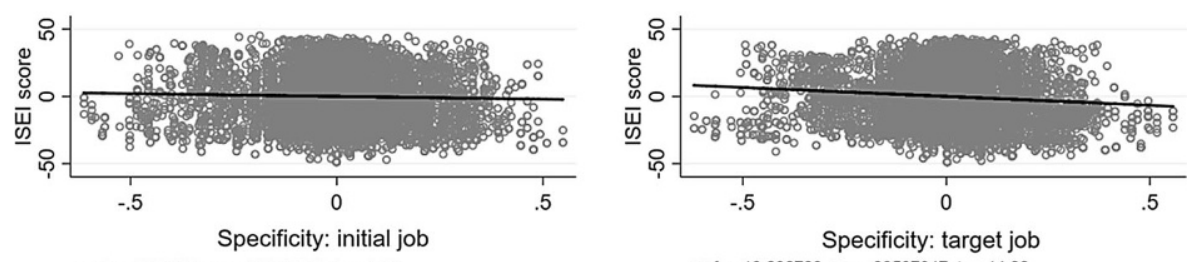

coef $=-4.206147$, se $=.94807055, t=-4.44$

Fig. 1 Correlation of ISEI scores and occupational characteristics of the initial and target job 
ated with standardized certificates. In the case of licensed occupations, the situation is exactly the opposite: these usually belong to occupations associated with high status, as confirmed by the plots. The small, negative relationship between skills specificity and status again seems to be plausible. Occupations with specific skills are found mainly in vocational training occupations, which usually have a lower status, whereas high-status academic occupations are associated with more general skills (Hall 2010). There is only a small proportion of unskilled occupations in the sample-usually nonstandardized, nonlicensed, and not very specific- that do not appear to count here. Additionally, the plots show that the correlation of target occupations and ISEI scores is always larger than that of initial occupations and ISEI scores. This means that these correlations become more evident the more employment episodes someone has already experienced.

As we are particularly interested in how the individual status changes are related to standardization, licensing, and skills specificity of the initial and target occupations, we correlate these variables pairwise. Individual status changes are calculated as the difference between the ISEI score of a target occupation and the ISEI score of the corresponding initial occupation. We find that status changes are correlated negatively with standardized certificates in the target occupation $(-0.11)$ as well as with occupational licensing $(-0.13)$ and skills specificity $(-0.05)$ in the initial occupation. Status changes are correlated positively with standardized certificates (0.09) in the initial occupation, as well as with occupational licensing (0.15) and skills specificity (0.05) in the target occupation (see column A in Table 3). In other words, improvements in status are achieved by quitting occupations with standardized certificates and entering licensed and/or specific occupations. From Table 3, we also see that within each occupational characteristic, the initial and target occupations correlate highly, indicating that most switches happen between jobs with similar standardization, licensing, and skills specificity. This condition also applies to switches within

Table 3 Correlations of status changes and occupational characteristics

\begin{tabular}{|c|c|c|c|c|c|c|c|}
\hline $\begin{array}{l}\text { Occupational characteris- } \\
\text { tics }\end{array}$ & $\mathrm{A}$ & $\mathrm{B}$ & $\mathrm{C}$ & $\mathrm{D}$ & $\mathrm{E}$ & $\mathrm{F}$ & G \\
\hline A) Status changes & 1.00 & - & - & - & - & - & - \\
\hline $\begin{array}{l}\text { B) Standardized initial } \\
\text { occupation }\end{array}$ & $0.09 *$ & 1.00 & - & - & - & - & - \\
\hline $\begin{array}{l}\text { C) Standardized target } \\
\text { occupation }\end{array}$ & $-0.11 *$ & $0.55^{*}$ & 1.00 & - & - & - & - \\
\hline $\begin{array}{l}\text { D) Licensed initial occu- } \\
\text { pation }\end{array}$ & $-0.13^{*}$ & $-0.23 *$ & $-0.14^{*}$ & 1.00 & - & - & - \\
\hline $\begin{array}{l}\text { E) Licensed target occu- } \\
\text { pation }\end{array}$ & $0.15^{*}$ & $-0.16^{*}$ & $-0.23^{*}$ & $0.66^{*}$ & 1.00 & - & - \\
\hline $\begin{array}{l}\text { F) Specific initial occupa- } \\
\text { tion }\end{array}$ & $-0.05^{*}$ & $-0.33 *$ & $-0.18^{*}$ & $0.46^{*}$ & $0.33^{*}$ & 1.00 & - \\
\hline $\begin{array}{l}\text { G) Specific target occupa- } \\
\text { tion }\end{array}$ & $0.05^{*}$ & $-0.18 *$ & $-0.34 *$ & $0.32 *$ & $0.45^{*}$ & $0.53 *$ & 1.00 \\
\hline
\end{tabular}

Source: NEPS-SC6 restricted sample; $N$ persons $=10,821 ; N$ observations $=25,964 ;$ years 1999-2017, own calculations

Note: Pearson's correlation coefficients

Significance level: ${ }^{*} p<0.001$ 
occupations. Moreover, standardized certificates correlate negatively with licensed and skills-specific occupations, and licensed occupations correlate positively with skills-specific occupations (see panels B to F in Table 3). The negative correlation between standardization and licensing derives from the fact that the proportion of standardization tends to decrease with increasing requirements, whereas the proportion of licensing tends to increase with increasing requirements, even if these relationships are not entirely linear.

\subsection{Initial and Target Occupations' Effects on Status Mobility}

After obtaining a descriptive picture of how occupational characteristics are related to each other and to status mobility, we now examine this relationship under the control of all further information in the m-logit model. The results are presented in Table 4 and displayed as average marginal effects (AMEs). Further occupational, individual, job, and industry characteristics are controlled for but not reported in the table. ${ }^{6}$

An advantage of the multinomial model is that the single effects of the outcome states can be balanced with those of the basic category. We find that standardized certificates increase the likelihood of remaining within an initial occupation by 3.4 percentage points. At the same time, standardized certificates decrease the likelihood of quitting an initial occupation through horizontal mobility by 3.9 percentage points or through downward mobility by 11.1 percentage points, and they increase the

Table 4 Effects of occupational characteristics on status mobility

\begin{tabular}{lllll}
\hline & $\begin{array}{l}\text { No mobil- } \\
\text { ity }\end{array}$ & Horizontal mobility & Upward mobility & Downward mobility \\
\hline Standardized & $0.034^{*}$ & $-0.039^{*}$ & $0.116^{* * *}$ & $-0.111^{* * *}$ \\
initial occupation & $(0.016)$ & $(0.018)$ & $(0.017)$ & $(0.016)$ \\
Licensed initial & $0.201^{* * *}$ & $-0.057^{*}$ & $-0.570^{* * *}$ & $0.426^{* * *}$ \\
occupation & $(0.022)$ & $(0.027)$ & $(0.024)$ & $(0.021)$ \\
Specific initial & $0.094^{* * *}$ & -0.012 & $0.056^{* *}$ & $-0.138^{* * *}$ \\
occupation & $(0.020)$ & $(0.020)$ & $(0.020)$ & $(0.018)$ \\
Standardized & $0.034 *$ & 0.014 & -0.028 & -0.020 \\
target occupation & $(0.017)$ & $(0.019)$ & $(0.016)$ & $(0.017)$ \\
Licensed target & $0.112^{* * *}$ & $-0.113^{* * *}$ & $0.389^{* * *}$ & $-0.389^{* * *}$ \\
occupation & $(0.023)$ & $(0.027)$ & $(0.021)$ & $(0.023)$ \\
Specific target & $0.150^{* * *}$ & $-0.063^{* *}$ & $-0.052^{* *}$ & $-0.034 *$ \\
occupation & $(0.020)$ & $(0.020)$ & $(0.020)$ & $(0.017)$ \\
Control variables & $\boldsymbol{N}$ & $\boldsymbol{N}$ & $\boldsymbol{V}$ & $\boldsymbol{V}$ \\
Observations & 25,964 & & & \\
\hline
\end{tabular}

Source: NEPS-SC6 restricted sample; $N$ persons = 10,821; years 1999-2017, own calculations Average marginal effects from multinomial logistic regressions; control variables not reported; clusterrobust standard errors in parentheses

Significance levels: ${ }^{*} p<0.05,{ }^{* *} p<0.01,{ }^{* * *} p<0.001$

6 The full model can be provided on request. 
likelihood of quitting it through upward mobility by 11.6 percentage points. These results support hypothesis $1 a$ and reproduce the findings of Damelang et al. (2015) on horizontal mobility and of Vicari (2018) on upward mobility. The likelihood of staying in a target occupation in which standardized certificates are usually required is again 3.4 percentage points higher than any kind of occupational or status mobility. The horizontal and vertical movements across status positions do not, however, significantly differ in the likelihood of entering a target occupation with standardized certificates. Thus, hypothesis $1 b$ is also supported by our results.

We find licensing to have much stronger effects on mobility outcomes. The likelihood that workers in a licensed initial occupation do not quit at all is 20.1 percentage points higher than the likelihood that they do quit. The likelihood of quitting a licensed occupation through status increases is 57 percentage points lower-the strongest effect we observe. As licensed occupations are associated with high-status values, it is plausible that there is little potential for further rise. Quitting a licensed occupation by switching occupations at the same status level is also unlikely-on a much smaller scale. Contradicting our hypothesis $2 a$, we find that it is 42.7 percentage points more likely that workers will quit a licensed occupation through status decreases. This finding only partially fits the results from previous studies, which were only based on occupational and not explicitly on status mobility (Damelang et al. 2015; Reichelt and Abraham 2017; Vicari 2018). Looking at the characteristics of the target occupation, we again see a positive likelihood of staying in a licensed occupation. The likelihood of entering a licensed occupation through horizontal mobility or through downward mobility is 11.3 or 38.9 percentage points lower respectively, and it is 38.9 percentage points higher in the case of someone moving from an occupation with a lower status to a licensed occupation with a higher status. This supports our assumption regarding "pre-stage" occupations: for example, when a legal expert becomes a lawyer by investing in obtaining a license. In sum, we find full support for hypothesis $2 b$.

Finally, switching an initial skills-specific occupation or quitting it through downward mobility is unlikely. However, a status advancement is 5.6 percentage points more likely from an initial skills-specific occupation. This happens, for example, when someone switches from skilled occupations in papermaking, printing, and technical media design, which are rather skills-specific, to less specific-skilled occupations in business management and organization, which, however, have a higher ISEI score. Thus, we find partial support for our hypothesis $3 a$, as the effect on horizontal mobility is not significant, and full support for our assumption regarding established career paths. The general negative effect of skills specificity on switching occupations is in line with the results of Vicari (2018) and Reichelt and Abraham (2017). This negative effect is more prominent when we regard the effect of skills specificity on entering an occupation. The likelihood of not becoming occupationally mobile is 15.0 percentage points higher than becoming mobile. The likelihood of entering a skills-specific target occupation through horizontal mobility is 6.3 percentage points lower; in the case of upward mobility, the likelihood is 5.2 percentage points lower, and in the case of downward mobility, it is 3.4 percentage points lower. This fully supports our hypothesis $3 b$. 


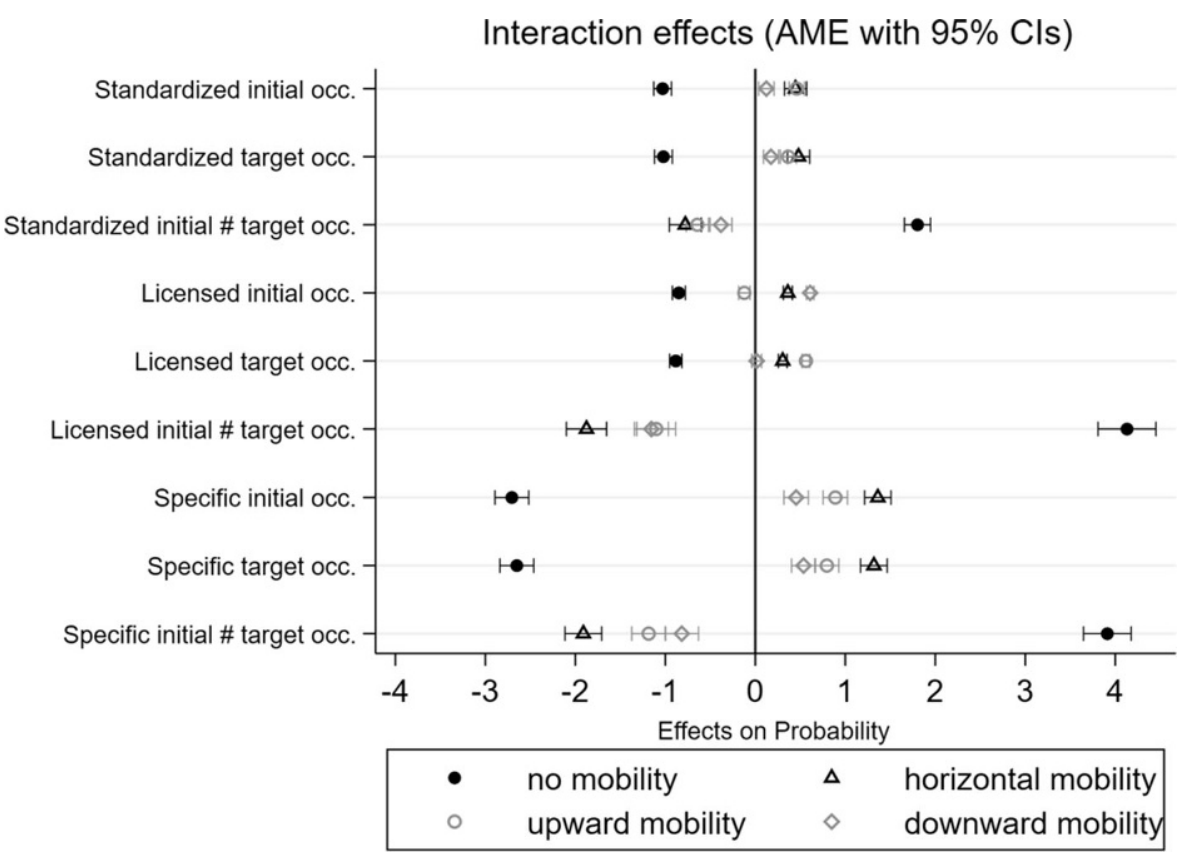

Fig. 2 Interaction effects of occupational characteristics on status mobility

In line with the descriptive results, it also seems to matter if someone switches between occupations with the same type of characteristics. To obtain a deeper understanding of how occupations shape career paths, we compute interaction effects between the initial and the target occupation for all three occupational characteristics. These are displayed as a marginal plot in Fig. 2. We find a clear pattern here: if the initial occupation requires standardized certificates but the target occupation does not, the likelihood of vertical and horizontal mobility is high. The same is true for switches from occupations without standardized certificates into occupations where standardized certificates are requested. However, horizontal and vertical status changes between two occupations that both require standardized certificates are highly unlikely. We observe a similar pattern for licensed and skills-specific occupations. There is only one exception to that pattern: switching from a licensed initial occupation to a nonlicensed target occupation through upward mobility is significantly less likely.

Bringing the results of all analyses together, we find that all three occupational characteristics in the initial and target occupations may create mobility constraints. For all three characteristics, job switches within one occupational main group are more likely than other types of occupational switches, which become the most unlikely between occupations with similar characteristics. On the other hand, we observe established career paths promoting upward mobility in some occupational segments. Consequently, status development is most likely to occur by switching from occupations with standardized certificates to occupations without standardized certificates and by switching from occupations requiring highly specific skills to 
occupations requiring more general skills. Status increases are also possible from nonlicensed occupations to licensed occupations, although an investment in further qualifications is necessary for a successful switch. Moreover, switching from a licensed to nonlicensed occupation increases the likelihood of downward mobility.

\section{Discussion and Concluding Remarks}

In this article, we have explored the question of how the characteristics of the initial and target occupations affect status mobility. In qualification-based labor markets, in which the assignment to positions is strongly linked to occupation-specific qualifications, occupations regulate entry into labor market segments. Usually, occupational mobility serves to enhance individual status over a life course or at least serves to correct disadvantageous starting conditions. This gains in relevance, especially in times when some occupations are shrinking and others are growing and the skills requirements in occupations are rapidly changing owing to technological progress. Thus, it is immensely important to understand the mechanisms of labor market regulation through occupations to provide recommendations on how to reintegrate individuals who are the most exposed to structural changes back into the labor market. However, when occupational mobility is hampered by closed labor market segments, status maintenance or development can hardly be realized. Our analyses show that certain occupational characteristics contribute to the accumulation of social inequalities by causing mobility constraints.

These results are in line with the current research on the regulatory power of occupations as institutions (Abraham et al. 2018). However, we successfully add two aspects to this research. First, we explicitly disclose the effects of the initial and target occupations with regulatory occupational characteristics on upward, downward, and horizontal mobility. Second, we theoretically and empirically embed our mobility analyses in the context of status mobility, as has already been recommended by Sørensen (1975), but which has not been focused on in prior research. In this way, we contribute to a deeper understanding of the effect of occupations on social inequality.

Our descriptive results show that occupational characteristics are basically correlated with different status positions. Occupations with standardized certificates, nonlicensed occupations, and occupations with high skills specificity are associated with a lower status, whereas occupations without standardized certificates, licensed occupations, and occupations with low skills specificity are associated with a higher status. This linear relationship is not what we would expect, because occupations with standardized certificates or specific skills are certainly not among those with the lowest status in Germany. Instead, helping jobs are actually associated with the lowest status. However, since we only allow employment episodes in our data that have a coded job title, we exclude all unspecified helper jobs. In consequence, the remaining specified helper jobs seems to have little effect on this correlation. For the majority of occupations, however, the linear relationship shown is plausible. Given this restriction, we aimed to explore whether a status development from occupations 
with standardized certificates, nonlicensed occupations, and occupations with high skills specificity is possible in a qualifications-based labor market.

In fact, we see that upward mobility is likely, as there seem to be established career paths for these switches. However, this is only the case if a switch is made to an occupation with the respective contrasting value of the characteristic. When switching from a nonlicensed to a licensed occupation to improve one's status, an investment in further qualifications to take the state examination and to obtain the license is necessary. This can hardly be a general recommendation for a way in which someone who is exposed to a shrinking occupational segment can become reintegrated into the labor market.

Although licensing has the strongest effects on occupational mobility-but allows for vertical movements - target occupations with specific skills are the most difficult to enter. Since $72 \%$ of the employment episodes are rather specific, it appears that the skills specificity of target occupations contributes to a previously underestimated high proportion of the low occupational mobility rate in Germany. This attribute was previously ascribed to licensing, which creates closed occupational segments. However, as mobility from specific to less specific occupations is possible and it is even associated with improvement in social status, we would recommend investing in more general skills, such as interactive or soft skills, to meet the challenges of technological progress.

Overall, we demonstrate that the occupational characteristics of the initial and target occupations each make an independent contribution to explaining mobility and status patterns. Nevertheless, there are limits to the explanatory power of our findings. Our analyses are restricted to the potential of the underlying data. Thus, the most critical factor is the temporal fixation of the occupational characteristics. As our occupational characteristics do not change over time, we have refrained from analyzing individual status mobility over the life course. However, this would come much closer to exploring intragenerational mobility than our static perspective on the effect of occupational characteristics on status changes.

Acknowledgements We would like to thank Christian Ebner, Andreas Haupt, Britta Matthes, and two anonymous reviewers, as well as the participants of the 2019 spring meeting of the DGS Section "Social inequality and analysis of social structures" and the participants of the ECSR 2019 Conference for helpful comments. This paper uses data from the National Educational Panel Study (NEPS): Starting Cohort Adults, https://doi.org/10.5157/NEPS:SC6:9.0.1. From 2008 to 2013, NEPS data were collected as part of the Framework Program for the Promotion of Empirical Educational Research funded by the German Federal Ministry of Education and Research (BMBF). As of 2014, NEPS has been carried out by the Leibniz Institute for Educational Trajectories (LIfBi) at the University of Bamberg in cooperation with a nationwide network.

Funding Open Access funding provided by Projekt DEAL.

Open Access This article is licensed under a Creative Commons Attribution 4.0 International License, which permits use, sharing, adaptation, distribution and reproduction in any medium or format, as long as you give appropriate credit to the original author(s) and the source, provide a link to the Creative Commons licence, and indicate if changes were made. The images or other third party material in this article are included in the article's Creative Commons licence, unless indicated otherwise in a credit line to the material. If material is not included in the article's Creative Commons licence and your intended use is not permitted by statutory regulation or exceeds the permitted use, you will need to obtain permission directly from the copyright holder. To view a copy of this licence, visit http://creativecommons.org/licenses/by/4. $0 /$. 


\section{References}

Abraham, Martin, Andreas Damelang and Andreas Haupt. 2018. Berufe und Arbeitsmarkt. In Arbeitsmarktsoziologie, eds. Martin Abraham and Thomas Hinz, 225-259. Wiesbaden: Springer VS.

Allmendinger, Jutta. 1989. Educational System and Labour Market outcomes. European Sociological Review 5:231-250.

Allmendinger, Jutta, Corinna Kleinert, Reinhard Pollak, Basha Vicari, Oliver Wölfel, Agnieszka Althaber, Manfred Antoni, Bernhard Christoph, Katrin Drasch, Florian Janik, Ralf Künster, Marie-Christine Laible, Kathrin Leuze, Britta Matthes, Michael Ruland, Benjamin Schulz and Annette Trahms. 2019. Adult education and lifelong learning. In Education as a lifelong process. The German National Educational Panel Study (NEPS), eds. Hans-Peter Blossfeld and Hans-Günther Roßbach, 325-346. Wiesbaden: Springer VS.

Becker, Gary S. 1962. Investment in Human Capital: A Theoretical Analysis. Journal of Political Economy 70:9-49.

Becker, Rolf, and Hans-Peter Blossfeld. 2017. Entry of men into the labour market in West Germany and their career mobility (1945-2008). Journal for Labour Market Research 50:113-130.

Best, Henning, and Christof Wolf. 2012. Modellvergleich und Ergebnisinterpretation in Logit- und ProbitRegressionen. Kölner Zeitschrift für Soziologie und Sozialpsychologie 64:377-395.

Bills, David B. 2003. Credentials, signals, and screens; explaining the relationship between schooling and job assignment. Review of Educational Research 73:441-469.

Blossfeld, Hans-Peter. 1985. Berufseintritt und Berufsverlauf. Mitteilungen aus der Arbeitsmarkt- und Berufsforschung 18:177-197.

Blossfeld, Hans-Peter, and Karl Ulrich Mayer. 1988. Labor market segmentation in the Federal Republic of Germany: an empirical study of segmentation theories from a life course perspective. European Sociological Review 4:123-140.

Blossfeld, Hans-Peter, Hans-Günther Roßbach and Jutta von Maurice. 2011. Education as a lifelong process. The National Educational Panel Study (NEPS). Zeitschrift für Erziehungswissenschaft 14.

Bol, Thijs, and Kim A. Weeden. 2015. Occupational Closure and Wage Inequality in Germany and the United Kingdom. European Sociological Review 31:354-369.

Breen, Richard, Kristian Bernt Karlson and Anders Holm. 2018. Interpreting and understanding logits, probits, and other nonlinear probability models. Annual Review of Sociology 44: 39-54.

Bryson, Alex, and Morris M. Kleiner. 2010. The Regulation of Occupations. British Journal of Industrial Relations 48:670-675.

Damelang, Andreas, Florian Schulz and Basha Vicari. 2015. Institutionelle Eigenschaften von Berufen und ihr Einfluss auf berufliche Mobilität in Deutschland. Schmollers Jahrbuch - Journal of Applied Science Studies 35:307-333.

Damelang, Andreas, Michael Stops and Martin Abraham. 2018. Occupations as labour market institutions: Occupational regulation and its effects on job matching and occupational closure. Soziale Welt 69:406-426.

Dengler, Katharina, and Britta Matthes. 2018. The impacts of digital transformation on the labour market: Substitution potentials of occupations in Germany. Technological Forecasting and Social Change 137:304-316.

Dengler, Katharina, Britta Matthes and Wiebke Paulus. 2014. Occupational Tasks in the German Labour Market. An alternative measurement on the basis of an expert database. FDZ-Methodenbericht $12 / 2014$.

Dengler, Katharina, Michael Stops and Basha Vicari. 2016. Occupation-Specific Matching Efficiency. IABDiscussion Paper 16/2016.

Ditton, Hartmut, and Kai Maaz. 2011. Sozioökonomischer Status und soziale Ungleichheit. Gegenstandsbereiche. In Empirische Bildungsforschung, eds. Heinz Reinders, Hartmut Ditton, Cornelia Gräsel and Burkhard Gniewosz, 193-208. Wiesbaden: Springer VS.

Dütsch, Matthias, Verena Liebig and Olaf Struck. 2013. Erosion oder Stabilität der Beruflichkeit? Eine Analyse der Entwicklung und Determinanten beruflicher Mobilität. Kölner Zeitschrift für Soziologie und Sozialpsychologie 65:505-531.

Esser, Hartmut. 2006. Institutionen als „Modelle“. Zum Problem der „Geltung“ von institutionellen Regeln und zur These von der Eigenständigkeit einer „Logic of Appropriateness“. In Ökonomischer und soziologischer Institutionalismus, eds. Michael Schmid and Andrea Maurer, 47-72. 2., durchges. Auflage. Marburg: Metropolis. 
Fitzenberger, Bernd, and Alexandra Spitz-Oener. 2004. Die Anatomie des Berufswechsels: Eine empirische Bestandsaufnahme auf Basis der BIBB/IAB-Daten 1998/1999. ZEW Discussion Paper No. 04-05.

Fletcher, Jason M. 2012. The Effects of First Occupation on Long Term Health Status: Evidence from the Wisconsin Longitudinal Study. Journal of Labor Research 33: 49-75.

Fuller, Sylvia. 2008. Job Mobility and Wage Trajectories for Men and Women in the United States. American Sociological Review 73:158-183.

Gangl, Markus. 2003. The Only Way Is Up? Employment Protection and Job Mobility among Recent Entrants to European Labour markets. European Sociological Review 19:429-449.

Ganzeboom, Harry B. G., Paul M. De Graaf and Donald J. Treiman. 1992. A Standard International SocioEconomic Index of Occupational Status. Social Science Research 21:1-56.

Georg, Walter, and Ulrike Sattel. 2006. Berufliche Bildung, Arbeitsmarkt und Beschäftigung. In Handbuch der Berufsbildung, eds. Rolf Arnold and Antonius Lipsmeier, 125-152. Wiesbaden: VS.

Giesecke, Johannes, and Jan Paul Heisig. 2010. Destabilisierung und Destandardisierung, aber für wen? Die Entwicklung der westdeutschen Arbeitsplatzmobilität seit 1984. Kölner Zeitschrift für Soziologie und Sozialpsychologie 62:403-435.

Gittleman, Maury, Mark A. Klee and Morris M. Kleiner. 2018. Analyzing the labor market outcomes of occupational licensing. Industrial Relations: A Journal of Economy Society 57: 57-100.

Hall, Anja. 2010. Wechsel des erlernten Berufs: Theoretische Relevanz, Messprobleme und Einkommenseffekte. In Berufsforschung für eine moderne Berufsbildung - Stand und Perspektiven, eds. Dieter Euler, Ulrich Walwei and Reinhold Weiß, 157-174. Band 24. Stuttgart: Franz Steiner.

Hanushek, Eric A., Ludger Woessmann and Lei Zhang. 2011. General Education, Vocational Education, and Labor-Market Outcomes over the Life-Cycle. IZA Discussion Paper 6083.

Haupt, Andreas. 2012. (Un)Gleichheit durch soziale Schließung. Kölner Zeitschrift für Soziologie und Sozialpsychologie 64:729-753.

Haupt, Andreas. 2016. Erhöhen berufliche Lizenzen Verdienste und die Verdienstungleichheit? Zeitschrift für Soziologie 45:39-56.

Haupt, Andreas, and Nils Witte. 2016. Occupational Licensing and the Wage Structure in Germany. KITWorking Paper Series in Sociology 4.

Hillmert, Steffen. 2011. Occupational Mobility and Developments of Inequality along the Life Course. European Societies 13:401-423.

Jarvis, Benjamin F., and Xi Song. 2017. Rising Intragenerational Occupational Mobility in the United States, 1969 to 2011. American Sociological Review 82:568-599.

Johnson, William R. 1978. The Theory of Job Shopping. Quarterly Journal of Economics 92:261-278.

Kambourov, Gueorgui, and Iourii Manovskii. 2009. Occupational Mobility and Wage Inequality. Review of Economic Studies 76:731-759.

Kleiner, Morris M. 2000. Occupational Licensing. Journal of Economic Perspectives 14:189-202.

Kleining, Gerhard, and Harriett Moore. 1960. Das soziale Selbstbild der Gesellschaftsschichten in Deutschland. Kölner Zeitschrift für Soziologie und Sozialpsychologie 12:86-119.

Konietzka, Dirk. 2008. Berufliche Ausbildung und der Übergang in den Arbeitsmarkt. In Bildung als Privileg. Erklärungen und Befunde zu den Ursachen der Bildungsungleichheit, eds. Rolf Becker and Wolfgang Lauterbach, 277-306. Wiesbaden: VS.

König, Wolfgang, and Walter Müller. 1986. Educational systems and labour markets as determinants of worklife mobility in France and West Germany: A comparison of men's career mobility, 1965-1970. European Sociological Review 2:73-96.

Kracke, Nancy, Malte Reichelt and Basha Vicari. 2018. Wage losses due to overqualification: The role of formal degrees and occupational skills. Social Indicators Research 139:1085-1108.

Leuze, Kathrin. 2007. What makes for a good start? Consequences of occupation-specific higher education for career mobility: Germany and Great Britain compared. International Journal of Sociology 37:29-53.

Longhi, Simonetta, and Malcolm Brynin. 2010. Occupational change in Britain and Germany. Labour Economics 17:655-666.

Matthes, Britta, and Basha Vicari. forthcoming. Indikator zur Messung der Ähnlichkeit von Berufen. FDZMethodenreport.

Maurice, Marc, François Sellier and Jean-Jacques Silvestre. 1979. Die Entwicklung der Hierarchie im Industrieunternehmen: Untersuchung eines gesellschaftlichen Effektes: Ein Vergleich Frankreich Bundesrepublik Deutschland. Soziale Welt 30:295-327.

Mayer, Karl Ulrich, and Glenn R. Carroll. 1987. Structural Constraints on Career Mobility. European Sociological Review 3:14-38. 
Mayer, Karl Ulrich, Daniela Grunow and Natalie Nitsche. 2010. Mythos Flexibilisierung? Wie instabil sind Berufsbiografien wirklich und als wie instabil werden sie wahrgenommen? Kölner Zeitschrift für Soziologie und Sozialpsychologie 62:369-402.

Miller, Robert A. 1984. Job Matching and Occupational Choice. The Journal of Political Economy 92:1086-1120.

Müller, Walter, and Yossi Shavit. 1998. The Institutional Embeddedness of the Stratification Process: A Comparative Study of Qualifications and Occupations in Thirteen Countries. In From School to Work, eds. Walter Müller and Yossi Shavit, 1-48. Oxford University Press.

Paulus, Wiebke, and Britta Matthes. 2013. The German classification of occupations 2010. Structure, coding and conversion table. FDZ-Methodenreport 08/2013.

Reichelt, Malte, and Martin Abraham. 2017. Occupational and Regional Mobility as Substitutes: A New Approach to Understanding Job Changes and Wage Inequality. Social Forces 95:1399-1426.

Rhein, Thomas, Parvati Trübswetter and Natascha Nisic. 2013. Is Occupational Mobility in Germany Hampered by the Dual Vocational System? The Results of a British-German Comparison. Schmollers Jahrbuch 133:203-214.

Schmelzer, Paul. 2012. The Consequences of Job Mobility for Future Earnings in Early Working Life in Germany-Placing Indirect and Direct Job Mobility into Institutional Context. European Sociological Review 28:82-95.

Sengenberger, Werner. 1987. Struktur und Funktionsweise von Arbeitsmärkten: die Bundesrepublik Deutschland im internationalen Vergleich. Frankfurt am Main: Campus.

Solga, Heike, and Dirk Konietzka. 1999. Occupational Matching and Social Stratification. Theoretical Insights and Empirical Observations Taken from a German-German Comparison. European Sociological Review 15:25-47.

Sørensen, Aage B. 1975. The Structure of Intragenerational Mobility. American Sociological Review 40:456-471.

Sørenson, Aage B., and Arne L. Kalleberg. 1981. An Outline of a Theory of the Matching of Persons to Jobs. In Sociological Perspectives on Labor Markets, ed. Ivar Berg, 49-74. New York: Academic Press.

Sorokin, Pitirim. 1927. Social mobility. New York: Harper.

Thurow, Lester C. 1975. Generating Inequality: Mechanisms of Distribution in the US Economy. New York: Basic Book

Topel, Robert H., and Michael P. Ward. 1992. Job Mobility and the Careers of Young Men. The Quarterly Journal of Economics 107:439-479.

Vicari, Basha. 2014. Degree of Standardised Certification of Occupations. An Indicator for Measuring Institutional Characteristics of Occupations (KldB 2010, KldB 1988). FDZ-Methodenreport 04/2014.

Vicari, Basha. 2018. Der Einfluss strukturierender Eigenschaften von Berufen auf horizontale und vertikale berufliche Mobilität im Kohortenvergleich. IAB-Discussion Paper 25/2018.

Weeden, Kim A. 2002. Why Do Some Occupations Pay More than Others? Social Closure and Earnings Inequality in the United States. American Journal of Sociology 108: 55-101.

Williamson, Oliver E. 1981. The Economics of Organization: The Transaction Cost Approach. American Journal of Sociology 87:548-577.

Windzio, Michael. 2013. Regressionsmodelle für Zustände und Ereignisse. Wiesbaden: Springer VS.

Wolbers, Maarten H.J. 2008. Increasing labor market instability among young people? Labor market entry and early career development among school-leavers in the Netherlands since the mid-1980s. In Young workers, globalization and the labor market: Comparing early working life in eleven countries, eds. Hans-Peter Blossfeld, Sandra Buchholz, Erzsébet Bukodi and Karin Kurz, 77-101. Cheltenham: Edward Elgar.

Basha Vicari 1979, Dr. rer pol., senior researcher at the Institute for Employment Research (IAB), Nuremberg, Germany. Research interests: empirical sociology of labor markets, occupational mobility and social inequality. Recent publication: Wage losses due to overqualification: The role of formal degrees and occupational skills. Social Indicators Research 139, 2018 (with N. Kracke and M. Reichelt).

Stefanie Unger 1987, Dr. rer pol., senior researcher at the Institute for Employment Research (IAB), Nuremberg, Germany. Research interests: empirical sociology of labor markets, health economics, social inequality and quantitative methodology. Recent publication: Age and gender differences in the impact of labour-market transitions on subjective health in Germany. Scandinavian Journal of Public Health 46, 2018 (with A. Tisch and S. Tophoven). 